THE ULSTER QUESTION SINCE 1945 


\section{Studies in Contemporary History}

Series Editors: T. G. Fraser and J. O. Springhall

\section{PUBLISHED}

T. G. Fraser The Arab-Israeli Conflict

James Loughlin The Ulster Question since 1945

Raymond Pearson The Rise and Fall of the Soviet Empire

William T. Martin Riches The Civil Rights Movement: Struggle and Resistance

Dennis B. Smith Japan: The Rise of an Economic Superpower

\section{FORTHCOMING}

Stephen Ryan The United Nations and International Politics

Dennis B. Smith China since 1945

\section{Studies in Contemporary History Series Standing Order ISBN 978-0-333-71706-6 hardcover ISBN 978-0-333-69351-3 paperback (outside North America only)}

You can receive future titles in this series as they are published by placing a standing order. Please contact your bookseller or, in the case of difficulty, write to us at the address below with your name and address, the title of the series and the ISBN quoted above.

Customer Services Department, Macmillan Distribution Ltd Houndmills, Basingstoke, Hampshire RG21 6XS, England 


\title{
The Ulster Question SINCE 1945
}

\section{James Loughlin}

\author{
Senior Lecturer in History
}

Magee College, University of Ulster

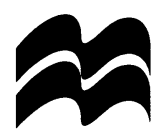


Softcover reprint of the hardcover 1st edition 1998 978-0-333-60615-5

All rights reserved. No reproduction, copy or transmission of this publication may be made without written permission.

No paragraph of this publication may be reproduced, copied or transmitted save with written permission or in accordance with the provisions of the Copyright, Designs and Patents Act 1988, or under the terms of any licence permitting limited copying issued by the Copyright Licensing Agency, 90 Tottenham Court Road, London W1P 9HE.

Any person who does any unauthorised act in relation to this publication may be liable to criminal prosecution and civil claims for damages.

The author has asserted his right to be identified as the author of this work in accordance with the Copyright, Designs and Patents Act 1988.

First published 1998 by

MACMILLAN PRESS LTD

Houndmills, Basingstoke, Hampshire RG21 6XS

and London

Companies and representatives throughout the world

ISBN 978-0-333-60616-2 ISBN 978-1-349-26708-8 (eBook)

DOI $10.1007 / 978-1-349-26708-8$

A catalogue record for this book is available from the British Library.

This book is printed on paper suitable for recycling and made from fully managed and sustained forest sources.

$\begin{array}{rrrrrrrrrr}10 & 9 & 8 & 7 & 6 & 5 & 4 & 3 & 2 & 1\end{array}$

$\begin{array}{llllllllll}07 & 06 & 05 & 04 & 03 & 02 & 01 & 00 & 99 & 98\end{array}$

Published in the United States of America 1998 by

ST. MARTIN'S PRESS, INC.,

Scholarly and Reference Division,

175 Fifth Avenue, New York, N.Y. 10010

ISBN 978-0-312-21446-3 
For Jacinta 


\section{CONTENTS}

Series Editors' Preface

Acknowledgements xii

List of Abbreviations xiii

Map of Northern Ireland $\quad$ xvi

Introduction $\quad 1$

Plantation, Myth and History 1

Nationalist Resurgence 3

Gladstonian Home Rule and Ulster $\quad 5$

From War to Partition 10

Northern Ireland: 'The Statelet Secured 13

Ulster Nationalists and Northern Ireland 16

The Inter-War Period $\quad 18$

King's Men $\quad 21$

1 Ulster: a Reconstituted Question 22

The Post-War Position $\quad 22$

Change and its Effects 23

Economic Decline and its Consequences 26

O'Neill and Reform $\quad 27$

Minority Grievances $\quad 29$

Party Politics and the Catholic Community 31

The Civil Rights Campaign $\quad 34$

From Agitation to Conflict $\quad 36$

Paisley and the Resurgence of Loyalist Extremism 39

Labour and Northern Ireland $\quad 45$ 
2 British Intervention $\quad 47$

$\begin{array}{lr}\text { Crisis Management } & 47\end{array}$

Reform and Reaction $\quad 49$

Republicanism and Nationalism Re-form $\quad 50$

Unionism: A Fracturing Movement $\quad 51$

Westminster Changes and Ulster Consequences $\quad 52$

The Crisis Escalates $\quad 54$

Faulkner and Internment $\quad 55$

Internment: The Consequences $\quad 58$

$\begin{array}{ll}\text { Prorogation } & 60\end{array}$

3 New Initiatives and Old Problems $\quad 64$

A New Order $\quad 64$

PIRA Violence and British Responses $\quad 66$

$\begin{array}{lr}\text { Loyalist Paramilitary Resurgence } & 68\end{array}$

$\begin{array}{ll}\text { Towards Political Accommodation } & 69\end{array}$

The Sunningdale Experiment $\quad 71$

The UWC Strike $\quad 74$

The Ulster Convention $\quad 77$

$\begin{array}{ll}\text { Ulsterisation } & 79\end{array}$

$\begin{array}{lr}\text { Security Initiatives and PIRA Reactions } & 81\end{array}$

The Blanket Protest $\quad 84$

Thatcher and the Hunger Strikes $\quad 85$

New Directions in Nationalist Politics $\quad 87$

$\begin{array}{ll}\text { Unionist Immobility } & 90\end{array}$

From Forum to Agreement $\quad 91$

4 Agreement and Process $\quad 95$

The Agreement Formalised $\quad 95$

Unionists Respond $\quad 97$

Nationalist Gains $\quad 101$

Anglo-Irish Difficulties 102

Republican Reaction 104

The Brooke Initiative 106

Hume and Adams Confer 109

A Dublin Boost 112

Retrieving the Initiative $\quad 115$

$\begin{array}{ll}\text { The Joint Declaration } & 117\end{array}$

Towards the Cessation 118

$\begin{array}{ll}\text { The Paramilitary Ceasefires } & 120\end{array}$ 
The Mitchell Report

Drumcree '96

Another Start

Drumcree '97

Conclusion

134

Bibliography

Index 


\section{SERIES EdITORS' PREFACE}

There are those, politicians among them, who feel that historians should not teach or write about contemporary events and people - many of whom are still living - because of the difficulty of treating such matters with historical perspective, that it is right to draw some distinction between the study of history and the study of current affairs. Proponents of this view seem to be unaware of the concept of contemporary history to which this series is devoted, that the history of the recent past can and should be written with a degree of objectivity. As memories of the Second World War recede, it is surely time to place in perspective the post-war history that has shaped all our lives, whether we were born in the 1940 s or the 1970 s.

Many countries - Britain, the United States and Germany among them - allow access to their public records under a thirty-year rule, opening up much of the post-war period to archival research. For more recent events, diaries, memoirs, and the investigations of newspapers and television, confirm the view of the famous historian, Sir Lewis Namier, that all secrets are in print provided you know where to look for them. Contemporary historians also have the opportunity, denied to historians of earlier periods, of interviewing participants in the events they are analysing. The problem facing the contemporary historian is, if anything, the embarrassment of riches.

In any case, the nature and extent of world changes since the late 1980s have clearly signalled the need for concise discussion of major themes in post-1945 history. For many of us the difficult thing to grasp is how dramatically the world has changed over recent years: the collapse of the Soviet Union and Russian communism; the end of Soviet 
hegemony over eastern Europe; the unification of Germany; the end of the Cold War; America's sense of a 'new world order'; the pace of integration in the European Union; the disintegration of Yugoslavia; the Middle East peace settlement; the continuing economic strength of Japan. Writing in a structured and cogent way about these seismic changes is what makes contemporary history so challenging, and we hope that the end result will convey some of this excitement and interest to our readers.

The general objective of this series, written entirely by members of the School of History, Philosophy and Politics of the University of Ulster, is to offer concise and up-to-date treatments of post-war themes considered of historical and political significance, and to stimulate critical thought about the theoretical assumptions and conceptual apparatus underlying interpretation of the topics under discussion. The series should bring some of the central themes and problems confronting students and teachers of recent history, politics and international affairs into sharper focus than the textbook writer alone could provide. The blend required to write contemporary history that is both readable and easily understood but also accurate and scholarly is not easy to achieve, but we hope that this series will prove worthwhile for both students and teachers interested in world affairs since 1945 . 


\section{ACKNOWLEDGEMENTS}

I have accumulated many debts in writing this book. The scholarly ones are listed in the bibliography. For their assistance I would like to thank the staffs of the several libraries I have used, especially that of Magee College. More personally, my family was very tolerant of the demands the project made on my time and most helpful in assisting its completion.

\section{Note on Terminology}

This work often refers to Northern Ireland in the period $1922-72$ as a 'statelet'. This term is sometimes used in a pejorative sense. I have employed it because it seems most appropriate to an entity which, while having many of the attributes of statehood, lacked constitutional independence.

James Loughlin 


\title{
LIST OF ABBREVIATIONS
}

\author{
AIA Anglo-Irish Agreement \\ CDU Campaign for Democracy in Ulster \\ CPNI Communist Party of Northern Ireland \\ CSJ Campaign for Social Justice \\ DUP Democratic Unionist Party \\ FOI Friends of Ireland \\ HCL Homeless Citizens League \\ IGC Inter-Governmental Council \\ INLA Irish National Liberation Army \\ INV Irish National Volunteers \\ IRA Irish Republican Army
}

NICRA Northern Ireland Civil Rights Association

NILP Northern Ireland Labour Party

NIO Northern Ireland Office

OIRA Official Irish Republican Army

PD People's Democracy

PIRA Provisional Irish Republican Army

PSF Provisional Sinn Fein

RUC Royal Ulster Constabulary

SAS Special Air Services

SDLP Social Democratic and Labour Party

UDA Ulster Defence Association

UDR Ulster Defence Regiment

UPNI Unionist Party of Northern Ireland

USC Ulster Special Constabulary (B Specials) 
xiv

Abbreviations

UUP Ulster Unionist Party

UUUC United Ulster Unionist Council

UVF Ulster Volunteer Force

UWC Ulster Workers Council 


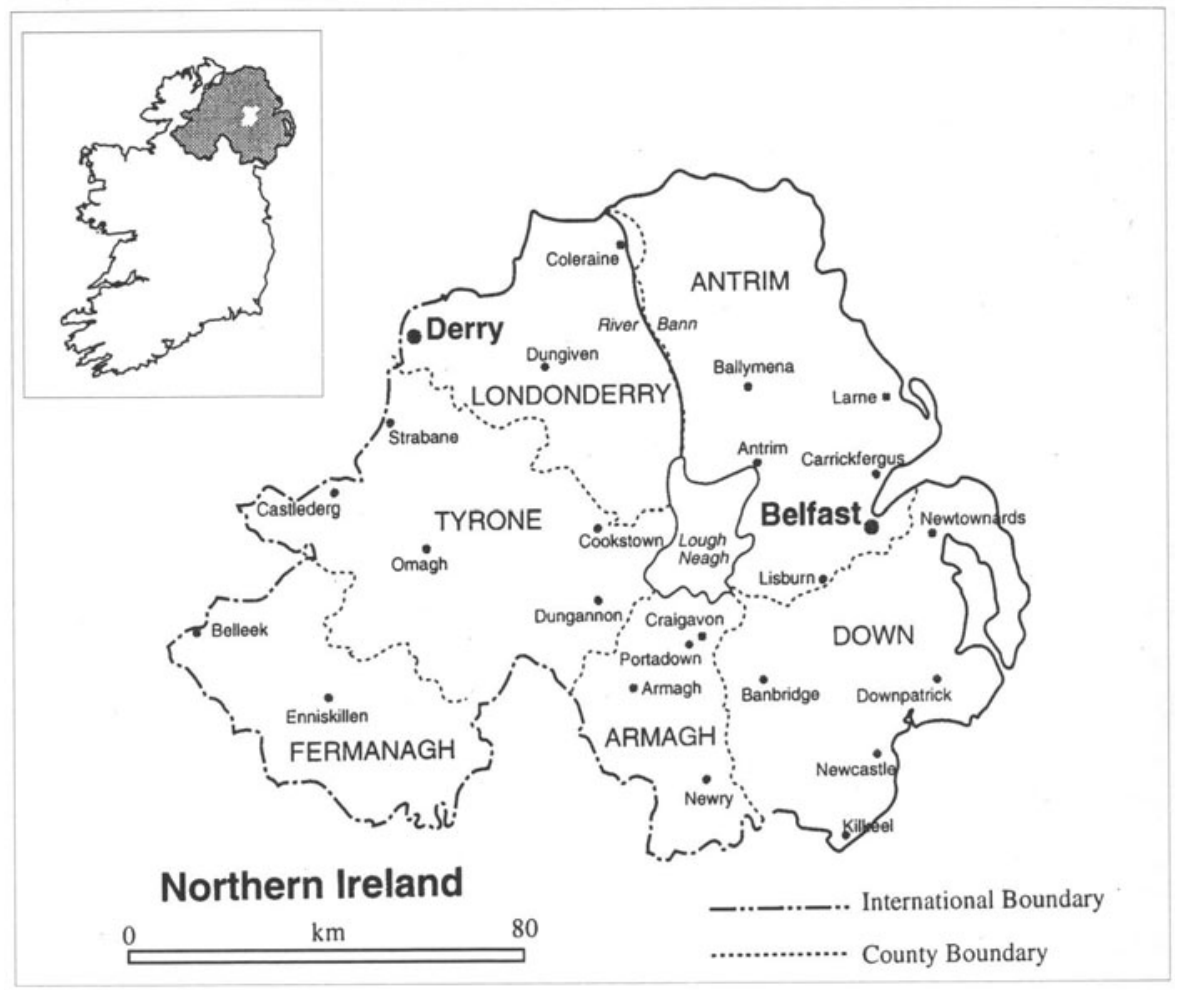

